\title{
Filing Suit in the Wrong Court and its Effect in Interrupting Period of Limitation
}

DOI http://dx.doi.org/10.4314/mlr.v13i1.6

Yehualashet Tamiru Tegegen*

"If a man neglects to enforce his rights, he cannot complain if, after a while, the law follows his example." (Oliver Holmes)

\begin{abstract}
Although the Federal Supreme Court rendered a sound decision on the effect of filing suit in the wrong jurisdiction with regard to the period of limitation, it failed to provide detailed analysis and reasoning. The importance of reasoning in judgment is well known. However, the Supreme Court Cassation Division in this case arrived at conclusion without deeply exploring the issues involved and without adequate analysis.
\end{abstract}

\section{Key terms}

Jurisdiction · Labour law · Collective disputes · Labour Relations Board · Period of limitation .

\section{Introduction}

As Callahan notes, "[J]udicial declarations representing the policy of statutes of limitations are numerous, but almost embarrassingly repetitive. Sometimes this declaration may serve the immediate purpose, but they are usually bare assertions offered without supporting analysis." 1 In the absence of details and descriptions that provide clarity, laws are susceptible to contradictory

\footnotetext{
* Yehualashet Tamiru Tegegen: LL.B ( AAU), LL.M ( University of Pretoria). I am very grateful to Dr. Mehari Redae and Amerti Solomon for their valuable comments on earlier draft. Email: yehuala5779@gmail.com

${ }^{1}$ Charles C. Callahan (1955), 'Statutes of Limitation-Background', Ohio State Law Journal, Vol. 16 No.2 p.32
} 
interpretations. The need for clarity in legislation and the quest for adequate analysis in court decisions apply to issues of jurisdiction and period of limitation. If there is an elaborated and deeper exploration, even the 'losing party' would not feel defeated and could accept it as fair end to his case. ${ }^{2}$

A defect in jurisdiction either pecuniary or material makes the decree null and void or subject to invalidation by the defendant. Failure to raise local jurisdiction and material jurisdiction by the defendant has different implications. ${ }^{3}$ Even if a court does not have local jurisdiction, it does not prevent it from giving a valid and enforceable judgment although the defendant may bring preliminary objection. This shows that lack of local jurisdiction makes the judgment voidable. However, if the court has no material jurisdiction, such defect will prevent it from rendering a valid judgment even if the defendant fails to invoke the issue. This makes the judgment void ab initio unlike local jurisdiction. This is because the court itself or the parties to the litigation cannot confer jurisdiction to the court when there is no material jurisdiction.

The effect of submitting a suit to the wrong jurisdiction regarding period of limitation raises questions. Professor Allen Sedler argued that filing a suit in a wrong jurisdiction will not interrupt period of limitation. ${ }^{4}$ The courts which have no jurisdiction have no right and competence to pass a valid judgment and hence the judgment is null and void. It indirectly means, the case is assumed to have never been brought before a court, and as a result, period of limitation shall not be interrupted.

On the other hand, Professor René David argued that despite filing in wrong jurisdiction, period of limitation will be interrupted right away. ${ }^{5}$ The reason for such argument is that if the purpose of period of limitation is to create diligent individuals, then the person who files in the wrong jurisdiction has clearly exhibited that. Such variation in perspectives has caused different lines of interpretation and contradictory judgments ${ }^{6}$ in the decisions of the Federal Supreme Court Cassation Division.

\footnotetext{
${ }^{2}$ See, for example, Roger Fisher and William Ury (1992), Getting into Yes: Negotiating an agreement without giving in, in Bruce Patten (eds.), $2^{\text {nd }}$ ed., (Random House Business Books), p.18

${ }^{3}$ Jean- Marc Baissu (2000), Commentary on the General Law of Contracts in the Ethiopian Civil Code (unpublished) pp. 47-48

${ }^{4}$ Robert Allen Sedler (1968), Ethiopian Civil Procedure Code, (Haile Sellasie I University)

${ }^{5}$ Baissu, supra note 3

${ }^{6}$ Cassation Decision File No. 16648 Volume 3 and Cassation Decision File No. 36730 Volume 9. In the former case, the court ruled out that period of limitation will interrupt only if the party files its claim in proper jurisdiction.
} 


\section{Period of Limitation: Meaning and Purpose}

There is no single acceptable definition for period of limitation or statute of limitation. Statutes of limitation can be defined as a legislative act restricting the time within which legal proceedings may be brought. ${ }^{7}$ In specific terms, it is the system rules that limits the period of time available to a person ("the plaintiff") to initiate a civil claim (also known as an "action") against another person ("the defendant"). ${ }^{8}$

Oliver Holmes had posed a question which still many scholars try to answer: What is the justification for depriving a man of his rights, a pure evil as far as it goes in consequence of the lapse of time? ${ }^{9}$ The limitation system is the product of the interplay between two competing sets of policies: those supporting barring out of time claims and those encouraging the resolution of all claims, whether timely or untimely, on their substantive merits. ${ }^{10}$ As Ochoa and Witich noted, period of limitation "reflects a delicate balance among the plaintiff's, defendant's and society's interest. They are designed to create predictability, uniformity and fairness by preventing litigation of stale claim." 11

According to Professor Tilahun Teshome, defendants should not live their entire lives fearing that they will be sued for the past deeds. ${ }^{12}$ In a US case, for example, it was stated that statutes of limitation "force plaintiffs to assert their claim in a timely fashion when the evidence and witnesses' memories are fresh. As a result in compelling circumstances, even wrong doers are entitled to assume that their sins may be forgotten."13

\section{Ethiopian Telecommunication Corporation $v$. Amare Gelaw}

This case ${ }^{14}$ involves an aspect of the relationship between period of limitation and lack of jurisdiction. The suit started in Dessie Woreda Court where the petitioner (at the Federal Supreme Court Cassation Bench) was the respondent. The plaintiff during the initial litigation (who is the respondent (at the Federal

\footnotetext{
${ }^{7}$ https://www.britannica.com/topic/statute-of-limitations,/ last accessed on 08 August,2018/

${ }^{8}$ Law Reform Commission (2009), Limitation of Actions, Consultation paper, p.2.

${ }^{9}$ Holmes (2009), The Path of the Law, The Floating Press, p. 37

${ }^{10}$ Tyler T. Ochoa and Andrew Witich (1997), 'The Puzzling Purposes of Period of Limitation', PAC Journal of Law Vol. 28, p. 454-455

${ }^{11}$ Ibid, p. 462

12 Tilahun Teshome (2003), Basic Principles of Ethiopian Contract Law (in Amharic), Addis Ababa University Press, p. 181.

${ }^{13}$ Agency Holding Co. v. Malley- Duff \& assoc. as quoted in Katharine F. Nelson (1993), "The 1990 Federal 'Fallback' Statutes of Limitations: Limitation by Default", Nebraska Law Review Vol. 72, Issue 2, p. 465.

${ }^{14}$ The Federal Supreme Court Cassation File No. 36730. In this case the petitioner was Ethiopian Telecommunication Corporation. The respondent was Amare Gelaw.
} 
Supreme Court Cassation Bench) submitted a statement of claim before Regional Labor Relations Board alleging that the present petitioner failed to grant promotion for which he was the only candidate. The reason for the rejection of his claim was that the diploma certificate brought by the present respondent was unknown and unregistered, while competing for the post.

The present petitioner argued that the Labour Relations Board has no jurisdictional competence to entertain the case and alternatively provided a reply on the merit of the case. The Regional Labour Relations Board, however, rejected the preliminary objection on jurisdiction and decided on the merit of the case. Aggrieved by the decision of Labour Relations Board, the present petitioner appealed to Amhara Region Supreme Court. The Supreme Court of the Region confirmed the decision of the Regional Labour Relations Board by virtue of Article 337 of the Civil Procedure Code. Then, the petitioner filed a petition of cassation at the Federal Supreme Court Cassation Bench which (under File No. 36730) reversed the holdings of the Labour Relations Board and Regional Supreme Court.

The Federal Supreme Court Cassation Bench ruled out that the case is not collective labour dispute and thus, the Regional Labour Relations Board has no jurisdiction to entertain the case. The respondent then opened a new file before Dessie Woreda Court. Nevertheless, the petitioner argued that the period of limitation has expired. The court rejected its preliminary objection by stating that filing of case even before a wrong jurisdiction interrupts the period of limitation and decided on the merit of the case. Aggrieved by this decision, the petitioner appealed to South Wollo Zonal Court. However, the court confirmed the decision of the lower court by citing Article 337 of the Civil Procedure Code.

The petition submitted to the Federal Supreme Court Cassation Division stated that the lower courts have made fundamental error of law while interpreting period of limitation. The petitioner further stated that the decisions of the lower courts lack clarity and sound reasoning. The petitioner argued that the reasoning of lower courts is against the clear provision of Articles 162-164 and Article 147 of the Labor Proclamation and Article 1851(1) of the Civil Code. The petitioner argued that lower courts in Ethiopia are required to enforce and give effect to the decision of Federal Supreme Court Cassation Bench by virtue of Article 2(1) of Proclamation No. 454/2005. The respondent, on his part, argued that the lower courts have not committed error in interpretation.

Under File No. 16648, the Federal Supreme Court Cassation Bench had held that filing a suit in a wrong jurisdiction will not interrupt period of limitation. In spite of this decision that was rendered earlier by the Federal Supreme Court Cassation Division, the petitioner argued that as lower courts had committed fundamental error of law, the courts' decision should be rectified by the decision of Cassation Bench. 


\section{Holding of the Cassation Bench}

After examining the issue whether or not the decision of lower court regarding period of limitation is appropriate, the Cassation Bench held that any claim brought before wrong jurisdiction will interrupt period of limitation and overruled its holding under the same subject matter under File No. 16648. The Cassation Bench reasoned out that decision regarding period of limitation should be interpreted in light of the basic purpose and objectives of the law. The court stated that the very purpose of the period of limitation, as it could easily be inferred from various provisions, is to encourage people to be more active and assertive in enforcing and claiming any right due to them. As far as the labour case is concerned, the Labour Relations Board has its own power and function as per the Labour Proclamation.

On the belief that the issue is collective labour dispute, the respondent brought the claim before Labour Relations Board and the Board decided the case after rejecting the preliminary objection. This shows that the respondent had taken reasonable measure, and the argument that filing of suit in a wrong jurisdiction will not interrupt period of limitation is unacceptable. Before accepting or rejecting a case, the court is supposed to examine whether it has jurisdiction. The Labor Relations Board should have promptly examined whether the case falls within its competence.

Moreover, the issue of period of limitation should be interpreted in light of the right to access to justice enshrined under Article 37 of the FDRE Constitution. The basic principle of interpretation and experiences of other countries show that period of limitation should be interpreted very narrowly. Based on these reasons, the Cassation Bench held that filing a case will interrupt the period of limitation even if the filing is made in a wrong jurisdiction.

\section{Period of limitation under Ethiopian Law: An overview}

There is no legal system which fails to recognize the importance of period of limitation. Ethiopia is, indeed, not an exception in this regard. History of period of limitation in Ethiopia can be traced back to the Fetha Negast. ${ }^{15}$ This law contained period of limitation provisions in three areas: contract of donation, contract of loan and inheritance. ${ }^{16}$

The Federal Constitution made it clear under Article 28 (1) that there is no period of limitation for crimes against humanity. The same provision stipulates

${ }^{15}$ See Abba Paulos Tzadua (2009), The Fetha Negast: The Law of the Kings, Peter L. Strauss (ed.) (Carolina Academic Press), p.42.

${ }^{16}$ Epherem Asamre (2016), Period of Limitation in Ethiopia (in Amharic), Nebadan PLC publisher, p. 12. 
that these crimes cannot be subject to amnesty or pardon by the legislative or any other state organ. It is important to note that the crimes listed under Subarticle 1 are illustrative, and not exhaustive. This can be inferred from the words 'such as'. There is international consensus regarding the non-applicability of period of limitation for crimes against humanity. This is justified by the gravity of the crime and thus deserves punishment as a matter of morality and fundamental consideration of justice. ${ }^{17}$

In contract law, Article 1845 of the Civil Code states that "unless otherwise provided by law", the period of limitation for "actions for the performance of a contract, actions based on the non-performance of a contract and actions for invalidation of a contract" is ten years. ${ }^{18}$ It seems that this provision is also applicable to other areas of obligation for three reasons. First, the provision is extends to other areas, and this can be inferred from the phrase "unless otherwise provided by law". Second, this provision is found under the general provision of contract, which unless provided by special law it will have a gap filling role as stated under Article 1676(2). Third, Article 1677(1) of the Civil Code provides that the general provision of contract shall apply to obligations even if they do not arise out of a contract.

Likewise, René David had stated that "Article 1845 deals only with contractual rights while the rules dealing with limitation will no doubt be used with respect to other types of problems". He then argues that "limitation needs to be considered from different points of view in the areas of property and family law than in connection with contract. This fact seems to justify the restrictions contained in Article 1845." "19 Baissu also extends the application of this provision to other areas where period of limitation is not mentioned. ${ }^{20}$

The Labour Proclamation, i.e. Proclamation No. 377/2003, provides various types of period of limitations based on the nature of the relief sought. The general principle is provided under Article 162(1) which states that unless a specific time limit is provided in the Labour Proclamation or other relevant law, an action arising from an employment relationship shall be barred by limitation after one year from the date on which the claim becomes enforceable. The same

${ }^{17}$ R.A Kok (2007), Statutory Limitations in International Criminal Law (University of Amsterdam), p. 15.

${ }^{18}$ According to Article 1846, the period of limitation runs from the day when the obligation is due or the right under the contract could be exercised. And the general rule in contract is that the cause of action accrues, not when the damage is suffered, but when the breach takes place, Joseph Chitty (1999), Chitty on Contracts: General Principles, Volume 1, $28^{\text {th }}$ ed. (Sweet and Maxwell Limited) pp. 1409-1410.

${ }^{19}$ René David (1973), Commentary on Contracts in Ethiopia, translated by Michael Kindred (Haile Selassie I University), p. 89.

${ }^{20}$ Baissu, supra note 3, p. 217. 
proclamation also made it clear that reinstatement claim will be barred unless it is brought within three months ${ }^{21}$; and payment of wages, overtime and other payments will be barred unless they are brought within six months from the due date. $^{22}$ The Labour Proclamation further stipulates that the provisions of the Civil Code regarding period of limitation may apply by analogy for labour case for which period of limitation is not provided. ${ }^{23}$

\section{Justifications for Interrupting Period of Limitation for Suit Filed in the Wrong Jurisdiction}

For the following reasons, period of limitation should be interrupted even if a suit or statement of claim is filed in a wrong jurisdiction.

\subsection{Intent of the law maker}

One of the cardinal rules of interpretation is reference to the intention of the law maker. Sound decision springs from finding the true intention of the law maker and interpret the law according to legislative intent. The initial draft of the Civil Code had certain provisions on interpretation and application of the law. This part has, however, been excluded in the final draft for unknown reason. ${ }^{24}$

The duty of the [judiciary] is to discover and to act upon the true intention of the legislature- the mens or sententia legis. ${ }^{25}$ According to the drafter of the Civil Code of Ethiopia, René David, "a court action interrupts the period of limitation only if the debtor receives notice of it" and he noted that where notice for performance is given to the debtor, "it is not essential that the action have been brought before the proper court. In case it is brought in the wrong court, it will serve as notice of default and the Code states that the default notice is sufficient to interrupt the period of limitation."

When the intent of the legislature is clear, the court should give effect to that. Jean- Marc Baissu, argued that the logic of this situation should be extended to the situation where the court is territorially incompetent:

"Where an application has been filed with a court which does not have territorial jurisdiction, the latter will of course have to declare the file inadmissible. But the fact remains that the creditor has clearly stated his will

${ }^{21}$ Labour Proclamation No. 377/2003, Federal Negarit Gazeta, $10^{\text {th }}$ year No. 12, Article 162(2) (herein after Labour Proclamation).

${ }^{22}$ See, Article 162(3) of the Labour Proclamation. However, the Cassation Bench has (under File No. 32545) extended the period limitation for provident fund to ten years.

${ }^{23}$ Article 162(5) of the Labour Proclamation.

${ }^{24}$ René David as quoted in George Krzeczunowicz (1964), 'Statute Interpretation in Ethiopia', Journal of Ethiopian law, Volume 1, No. 2, p. 317.

${ }^{25}$ Harry B. Littell (1945), 'A Comparison of the Statutes of Limitations', Indiana Law Journal, Vol. 23 Issue 1, p. 3. 
to interrupt limitation; he should not be penalized for a mistake which may be a very technical one committed by a layman, and therefore very much excusable." 26

\subsection{Procedural law as a means not an end}

Robert Allen Sedler stated that "striking out of a suit does not of its own force preclude the institution of a fresh suit with respect to the same cause of action" because it is considered "as if the first suit had never been filed, since the court did not determine the merits of the controversy." However, he noted that:

"the filing of a fresh suit may be precluded by other circumstances, and, if so, the fact a suit was once filed is of no benefit to the plaintiff. So, if at the time the fresh suit was filed, the statute of limitations had expired, that defense would be open to the defendant; even though the statute had not run at the time the original suit was filed." 27

However, there are gaps in this argument when we see in light of the purpose of Civil Procedure Law. The same author states that the purpose of procedure is only a means to end; it is not an end in itself. "Procedure has utility only insofar as it enables the court to make a fair and proper disposition of a case before it. When determining the proper procedure to follow excessively delays the trial of the merits of the case or when a party's rights are lost because of procedural errors, procedure will not serve its intended purpose." ${ }^{28}$ Thus, period of limitation being one of procedural matters should not defeat substantive rights provided under various law of the land.

The usual way of drawing the demarcation line between procedural law and substantive law is by referring to the remedy or rights of individual. If the matter is related to a party's right then it is substantive parts of the law whereas if the issue only relates to his remedy then it is procedural law. ${ }^{29}$ What happens at the end of the period of limitation is that the right is not extinguished but the remedy to take legal proceedings in respect of that right becomes barred. ${ }^{30}$ Thus, period of limitation only affects the remedy and not the right per se. It is thus a procedural matter which is an affirmative defense available for debtor.

\footnotetext{
${ }^{26}$ Jean- Marc Baissu, supra note 3, p. 155.

${ }^{27}$ Sedler, supra note 4, p. 179.

${ }^{28}$ Id., p. 2.

${ }^{29}$ The Law Commission [UK], (1980), Classification of Limitation in Private International Law, Working Paper No. 75 , p. 3.

${ }^{30}$ Law Commission of India (2005), Transitional Litigation-Conflict of Laws-Law of Limitation, $193{ }^{\text {rd }}$ Report, p. 11.
} 


\subsection{Purposive interpretation}

In some instances, mechanical and literal interpretation might lead to injustice and defeat the very purpose of the law. Depending on the case, the court may thus follow functional approach. It has been said that every law is designed to further the ends of justice and not to frustrate it on mere technicality. Although the function of the courts is only to expound the law and not to legislate, the legislature cannot be expected to resolve every difficulty in the implementation of its intention and the spirit of the law. In such circumstance, it is the duty of the court to mould or creatively interpret the legislation. The statute must be interpreted to advance the cause of statute and not to defeat it. ${ }^{31}$

One of the policy justifications underpinning limitation of action is to encourage plaintiffs to be more diligent and responsible in pursuing their claims. There is, however, disagreement as to whether this policy justification can stand alone. Some suggest that this policy is merely a means of implementing other policies. Ochoa \& Witich argue otherwise by using biblical quotes and other proverbs:

"This argument, however, overlooks the fact that limitation of actions also satisfies certain psychological, cultural and moral imperative. This is also expressed in the long-standing Christianity religion beliefs that time is the property of [G]od and it is a sin to waste time through delay or in efficiency. This altitude is displayed in a variety of popular saying such as the early bird catches the worms and never put off until tomorrow what you can do today." 32

If the plaintiff brings a court claim in the wrong jurisdiction, he has shown unequivocally that he is not sleeping over his right and is rather diligently asserting his rights. As a result, if a court holds that filing suit in wrong jurisdiction does not interrupt period of limitation, the purpose of the law will be defeated.

There is the principle that ignorance of the law is not a defense. However, a plaintiff who brings his/her claim in wrong jurisdiction has only misperceived the law but is not ignorant about the law in the strict sense. As a result, no valid reason seems to exist to extend ignorance of law to the issue of mis-appreciation of law.

${ }^{31}$ Avtar Singh (2006), Introduction to Interpretation of Statutes, $2^{\text {nd }}$ ed. (Wadhwa and Company Nagur Publisher), p. 54.

${ }^{32}$ Ochoa \& Witich, supra note 10, p. 489. 
The policy justification behind the general principle ignorantia juris non excusat is well stated when one author said "ignorance of law excuses no man not that all men know the law, but it is an excuse every man will plead and no man can tell how to confute him." "33 A plaintiff who in time but unknowingly filed his claim in wrong jurisdiction has clearly exhibited his intention to claim his/her rights. Had the plaintiff known the proper forum or had the court promptly rejected his claim thereby directing the plaintiff to the right jurisdiction, the claim could have been filed in the court having jurisdiction.

Moreover, a mistake based upon reasonable reliance on the dispute resolution body (which has received a claim to provide remedy) with the genuine belief that it has competence to entertain the case in indeed an error, but not an entire ignorance of law. Unlike the obvious case of ignorance of law, in such cases the plaintiff has already taken steps.

\subsection{The complexity of jurisdiction and the constitutional right of access to justice}

Jurisdiction can be broadly defined as the power of a court to hear and determine a case. ${ }^{34}$ While explaining Article 2246 of the French Civil Code, Planiol stated that questions of jurisdictions are hard to decide and parties often make mistakes about them, courts themselves sometimes go wrong about their jurisdiction. ${ }^{35}$ It is for this reason that Article 2246 of the French Civil Code provides that a citation interrupts prescription even if it be issued before a court without jurisdiction. Thus a harm is obviated whatever may be the nature of the incompetence and however serious may have been the mistake made; the plaintiff is protected by it. ${ }^{36}$ If identifying jurisdiction involves technical elements, the judge is justified in interrupting period of limitation even if the suit is filed in the wrong jurisdiction.

Access to justice is not absolute right, and it can be limited by imposing reasonable time limits to promote administration of justice. However, such restrictions must not impair the essence of the right, ${ }^{37}$ and it should be interpreted reasonably in such a manner that access to justice of a plaintiff is not denied, as long as he/she has filed his/her claim even if it is filed in the wrong jurisdiction.

\footnotetext{
${ }^{33}$ John Sedlen (1716), Table talk-law, $3^{\text {rd }}$ ed. p.61 as quoted in (1977), 'Ignorance or Mistake of the Law', Maryland Law Review, Vol. 37, Issue 2, p. 420.

${ }^{34}$ Baissu, supra note 26, p. 19.

${ }^{35}$ Marcel Planiol (1993), Treatises on Civil Law, Volume 1 Part. 2 (12 ${ }^{\text {th }}$ ed.) (St. Paul west publisher Co.), p. 234.

${ }^{36}$ Ibid.

${ }^{37}$ Handbook on European Law Relating to Access to Justice (2016), p. 28.
} 


\subsection{Period of limitation should be construed narrowly}

The tendency is to construe statute of limitation strictly. ${ }^{38}$ It is well established and settled principle that every person has a right to bring his grievance before the law to get remedy. "A suit for its maintainability requires no authority of law and it is enough that no statute bars the suit." $" 39$ The general principle is that when there is a right, there is a remedy. Thus, period of limitation is an exception to this established governing principle. Again, it is one of the prevailing rules of interpretation that exception should be interpreted narrowly. This should be especially the case when the issue is liberative prescription. ${ }^{40}$

\subsection{Prohibition of adding words/phrases than provided by the legislature}

It is one of the rules of interpretation that judges are not allowed to add or correct the text of the law. If there is "a defect or an omission in the words used by the legislature, the court would not ... correct or make up the deficiency" and courts cannot "add words to a statute ... which are not there, especially when the literal reading produces on intelligible result."

Words may be added, altered or modified only when it becomes necessary to prevent a provision from becoming unintelligible, absurd, unreasonable, unworkable or totally irreconcilable with the rest of the statute,. ${ }^{42}$ Careful reading of Article 1851(b) of the Civil Code shows that if the creditor brings action against debtor to perform its obligation, it will interrupt period of limitation. The provision does not qualify whether the action was brought in a court having jurisdiction. And hence, in the absence of any qualification, it is not up to the court to include conditions which were not there in the beginning.

\subsection{Experience of the "source" countries}

The drafter of the Civil Code indicated that the Civil Code tried to incorporate the custom, beliefs and laws of Ethiopia (mainly Fetha Negast). However, he stated that the western contribution is predominant and in some cases even exclusive, in those parts of the Civil Code where Ethiopian customs provide no assistance. This is particularly true for most of Books IV and V of the Civil

\footnotetext{
${ }^{38}$ Littell, supra note 25, p. 28.

${ }^{39}$ Granga Bai V. Vijail Kumar, AIR 1974 SC 1126 para 15available at https://indiankanoon.org/doc/1350326/ last access on 08 May 2018/

${ }^{40}$ There are two kinds of period of limitation: positive (or acquisitive) and negative (or extinctive). The former one is the creation of a right, the latter on the other hand is the destruction of right by elapse of period of limitation, John W. Salmond, Jurisprudence, (W.k Thomas\& Co. printer) (1902) p. 530

${ }^{41}$ Dadi Jagnnadham v. Jammulu Ramulu and others (2001) 7 SCC 71, para 15 available at https://indiankanoon.org/doc/672592/ last access on 08 May ,2018/

${ }^{42}$ Avtar Singh, supra note 31, p.3
} 
Code. In these areas slices of Western Law have been imported to Ethiopia. ${ }^{43}$ The principal and most important sources of the Ethiopian Civil Code with respect to the law of obligations were the Swiss Federal Code of obligation and French Law. $^{44}$

As mentioned in the foregoing discussion, Article 2246 of the French Civil Code made it clear that filing in wrong jurisdiction will serve as a valid ground to interrupt the period of limitation. ${ }^{45}$ The Swiss federal act also embodies a similar provision. This can indeed inform the intent of the drafters behind Article 1851(b) of the Ethiopian Civil Code which states the effect of a statement of claim on the interruption of period of limitation.

\subsection{Constructive notice}

In a case between American Pipe Co. et al vs. State of UTAH et al, the court stated that one of the purposes of period of limitation is to promote justice by preventing surprise through the revival of claims that have been allowed to slumber until evidence has been lost, memories have faded and witnesses have disappeared. ${ }^{46}$ The court further stated that even if one has a just claim, it is unjust not to put the adversary on notice to defend within the period of limitation and the right to be free of stale claims in time comes to prevail over the right to prosecute them. ${ }^{47}$ As Bain and Colella noted, "[t]he statute of limitations is suspended when a plaintiff has actively pursued judicial remedies and puts the defendant on notice of the claims within limitations period, even if the individual plaintiff has not filed an action in a court of proper jurisdiction before the statutes expires." 48

Under Ethiopian law, after the plaintiff files a suit before the court, he/she is required to submit the statement of claim to the respondent so that the latter could submit statement of defence along with the arguments and evidence

${ }^{43}$ René David (1967), 'Source of the Ethiopian Civil Code', Journal of Ethiopian Law, Vol. 4 No. 2, p. 347.

${ }^{44}$ Id., p. 348.

${ }^{45}$ It's important to notice that the Louisiana Civil Code of 1825 , the French influence became completely dominant in the adoption of the texts not only from the Code Napoleon but also from the first French commentators whole works had already appeared, Joseph Dainow (1959), Planiol, Civil Law Treatise. An English translation prepared by the Louisiana State Law Institution from the original French Planiol, Lousiana Law Review Vol. 20, No. 1 p. 193.

${ }^{46}$ American Pipe and Construction Co. et al vs. State of UTAH et al 414U.S. 538(1974) para 24 available at https://www.law.cornell.edu/supremecourt/text/414/538 (Last accessed on 04 May, 2018), Infra note 47.

${ }^{47}$ Ibid.

${ }^{48}$ Adam Bain and Ugo Colella (2004), 'Interpreting Federal statutes of Limitation', Creighton Law Review, Vol. 37, p. 517. 
thereof. There are four modes of service under Ethiopian law i.e. personal ${ }^{49}$, constructive $^{50}$, post $^{51}$ and substitutive. ${ }^{52}$ Irrespective of mode of service the defendant is summoned, or the defendant is made aware of the fact that the plaintiff is pursuing his/her claim. The defendant will be well notified that the plaintiff is not sleeping over his rights. This automatically crosses out the justification of "surprise claim".

\section{Concluding Remarks}

The right to bring any justiciable matter to the court and being entitled to a remedy for that are enshrined in law. However, it is equally important that the aggrieved person should bring his/her claim to the appropriate court having the power and competence to entertain the case and render a valid judgment. One of the issues in this regard relates to lack of jurisdiction which can be raised as preliminary objection.

However, the effect of lack of jurisdiction on the period of limitation is controversial in Ethiopia because Article 1851(b) of the Civil Code prescribes for the interruption of period of limitation upon filing of a suit without description whether this includes filing a suit in the wrong court. This indeed amounts to prescription without description. Lessons can thus be drawn from Article 2246 of the French Civil Code (which is one of the sources of the Ethiopian Civil Code) which allows the interruption of period of limitation even if the process of filing a suit is conducted before a court without jurisdiction. The provision reads "A service of process, even before a judge without jurisdiction, interrupts prescription."

The Federal Supreme Court Cassation Bench which is empowered to render binding interpretation of law has provided different decisions in File numbers No. 16648 and 36730. It is commendable that the Cassation Bench held that filing a suit in wrong jurisdiction will interrupt period of limitation in File No. 36730 by reversing its earlier decision in File No. 16648. Yet, the Court could have elaborated the grounds for its decision in such a manner that it gives clarity to the decision that it has duly rendered in File No. 36730.

\footnotetext{
${ }^{49}$ Article 95(3) of the Civil Procedure Code.

${ }^{50}$ Id., Article 96.

${ }^{51}$ Id., Article 105.

${ }^{52}$ Id., Article 108.
} 